\title{
Detection of the Three Kunitz-Type Single Domains of Membrane-Bound Tissue Factor Pathway Inhibitor (TFPI) by Flow Cytometry
}

\section{Carsten Tiemann, Thomas Brinkmann and Knut Kleesiek}

Institut für Laboratoriums- und Transfusionsmedizin, Herz- und Diabeteszentrum Nordrhein-Westfalen, Universitätsklinik der Ruhr-Universität Bochum, Bad Oeynhausen, Germany

Summary: Tissue factor pathway inhibitor, a natural anticoagulant in the extrinsic pathway of blood coagulation, is associated with the endothelial membrane and presumed to be released by heparin.

For flow cytometric detection of membrane-bound tissue factor pathway inhibitor we synthesized polyclonal monospecific antibodies directed against each of the three Kunitz-type domains. Antisera were obtained by immunisation of rabbits with synthetic oligopeptides representing the reactive site of each domain. Kunitzdomain $\delta 1:{ }^{26}$ CAFKDDGPCKAIMKR ${ }^{41}$, domain $\delta 2:{ }^{101}$ EDPGICRGYITR $^{112}$ and domain $\delta 3:{ }^{192}$ PADRGLCRA$\mathrm{NENR}^{204}$.

Different cell lines (chondrosarcoma, synovial sarcoma, synovial cells, leukaemic monocytes) and endothelial cells were investigated by flow cytometric analysis using these antibodies. The three tissue factor pathway inhibitor domains were detected on the surface of all cells by the corresponding antisera. Similar results were obtained by immuno-histochemical staining. Since domain $\delta 3$ was recognised by the appropriate antibody, it would seem that this third domain is not the membrane binding site. To investigate the cellular tissue factor pathway inhibitor release, endothelial cells were cultivated with heparin. Protein resynthesis and translocation were inhibited by puromycin and monensin, respectively. After heparin incubation an increased tissue factor pathway inhibitor concentration was determined in the cell culture medium by a chromogenic substrate assay. However, the tissue factor pathway inhibitor density on the cell surface was not influenced by heparin, as shown by flow cytometry using the three tissue factor pathway inhibitor antisera. Our results suggest that functionally active tissue factor pathway inhibitor is not released from the cell surface. Therefore, the effect of heparin appears to be mediated by secretion of tissue factor pathway inhibitor from intracellular stores.

\section{Introduction}

Tissue factor pathway inhibitor has been detected in human plasma, where it is associated with, and regulated by, low density lipoprotein. It functions as a potent natural anticoagulant that regulates tissue factor-mediated coagulation inhibition in the extrinsic pathway $(1-3)$. The native inhibitor consists of three Kunitz-type inhibitor domains (1), connective chains and a negatively charged $\mathrm{N}$-terminus, the total relative molecular mass being approximately $M_{\mathrm{r}} 36000$ to $M_{\mathrm{r}} 42000$. The tissue factor pathway inhibitor gene has been localized on chromosome 2 and the primary structure contains 276 amino acids including an acidic $\mathrm{N}$-terminus, the three Kunitz-type inhibitory domains and a basic carboxy terminal end $(4,5)$. Kunitz-domain $\delta 1$ has been identified as the site of binding factor VIIa/tissue factor complex, while domain $\delta 2$ binds activated factor X (FXa). Tissue factor pathway inhibitor is mainly synthesized by vascular endothelium, where it is bound to heparan sulphate or glycosaminoglycans $(6,7)$, and by other cells, e. g. megakaryocytes and chondrocytes (8). There are three intravascular pools of tissue factor pathway inhibitor, in plasma, in platelets and on the endothelial cell surface. The pathway of tissue factor pathway inhibitor synthesis, its presentation on the cellular surface and its association with lipoproteins remains unclear (9). It has been suggested that domain $\delta 3$ is involved in the binding to the cell membrane, lipoproteins, or in tissue factor pathway inhibitor-degradation via low density lipoprotein receptor-related protein on hepatocytes (10).

Injection of heparin has been found to result in a rapid dose-dependent 2-10 fold increase of tissue factor pathway inhibitor concentration in plasma $(11,12)$. The endothelium bound tissue factor pathway inhibitor becomes evident after injection of heparin in amounts equivalent to $50-90 \%$ of the total intravascular pool (13). Moreover, heparin effects the release of tissue factor pathway inhibitor into endothelial cell culture supernatant when added to the medium (14). The increased tissue factor pathway inhibitor activity suggested that this inhibitor is involved in the post-heparin anticoagulant effect following heparin administration. A heparin binding site C-terminal from domain $\delta 3$ has been postulated as a mediator of heparin-induced tissue factor 
pathway inhibitor release from the cell surface (15). However, it is also presumed that tissue factor pathway inhibitor is released from intracellular stores (16). So far, no results have been reported that show the proteinturnover of membrane bound tissue factor pathway inhibitor.

We have already determined the influence of cyclosporine on the vascular endothelium in heart transplant patients, resulting in an increased tissue factor pathway inhibitor plasma concentration $(17,18)$. These results were described as cytotoxic or modulatory effects on the endothelial cells (19).

In the present study we describe the flow cytometric detection of tissue factor pathway inhibitor on endothelial cells using three monospecific tissue factor pathway inhibitor-antisera which recognize the reactive site of Kunitz-type domain $\delta 1$ and $\delta 2$ as well as the corresponding region of domain $\delta 3$. We investigated the influence of heparin on the release of membrane-bound tissue factor pathway inhibitor from endothelial cells by flow cytometry, and we suggest a potential mechanism for tissue factor pathway inhibitor release from the vascular endothelium.

\section{Materials and Methods}

All chemicals were purchased from the Sigma (Deisenhofen, Germany) unless otherwise stated.

\section{Synthesis of polyclonal rabbit antisera}

The synthesis of the oligopeptides ${ }^{26}$ CAFKDDGPCKAIMKR ${ }^{41}$, ${ }^{101}{ }^{E D P G I C R G Y I T R}{ }^{112}$ and ${ }^{192}$ PADRGLCRANENR ${ }^{204}$ and the immunisation of rabbits were performed using standard techniques by QCB Inc. (Hopkinton, MA). For further use the antisera were heated for $30 \mathrm{~min}$ at $56^{\circ} \mathrm{C}$ and the IgG fraction was separated by $\left(\mathrm{NH}_{4}\right)_{2} \mathrm{SO}_{4}$ fractionation at $35 \%$ saturation followed by Protein $\mathrm{A}$ affinity chromatography to remove residual proteins. The IgG was then dialysed against $\mathrm{H}_{2} \mathrm{O}$. Aliquots were then stored at $-20^{\circ} \mathrm{C}$ until further use. As negative control non-immune rabbit IgG was prepared from preimmunserum by $\left(\mathrm{NH}_{4}\right)_{2} \mathrm{SO}_{4}$ precipitation followed by dialysis as described above. Protein A absorption was omitted.

\section{Determination of cross-reactivities}

All antisera were tested against each oligopeptide for specificity and to exclude cross-reactivity. The antigens were immobilized on an Immobilon $\mathrm{AV}^{\circledR}$ membrane (Millipore, Eschborn, Germany) and incubated with each antiserum after 20 min blocking with $20 \mathrm{~g} / 1$ casein. The detection was performed by standard methods using anti-rabbit horse radish peroxidase ${ }^{1}$ ) monoclonal antibodies.

Identification of tissue factor pathway inhibitorspecific mRNA by reverse transcription PCR

For reverse transcription PCR the total $\mathrm{mRNA}^{2}$ ) was isolated from different cell lines [endothelial cells (ECV304, EA.hy 926), chon-

\section{1) Enzymes:}

Factor VII (EC 3.4.21.2)

Factor X (EC 3.4.21.6)

Peroxidase from horseradish (EC 1.11.1.7) drosarcoma (SW1353), synovial sarcoma (SW982), synovial cells (McCoy) and leukaemic monocytes (THP-1)] according to the protocol from InstapureRNA-Kit (Eurogentec, Seraing, Belgium). Reverse transcription was performed with $1 \mu \mathrm{g}$ RNA and $7 \mathrm{pmol}$ oligo $\mathrm{d}(\mathrm{T})_{15}$ primer by incubation at $40^{\circ} \mathrm{C}$ for $90 \mathrm{~min}$ with $10 \mu \mathrm{mol}$ dNTP and $200 \mathrm{U}$ reverse transcriptase. The synthesized cDNA/ RNA hybrids were immediately used for the $\mathrm{PCR}^{2}$ ).

The following tissue factor pathway inhibitor specific primers were used, resulting in the entire sequence of tissue factor pathway inhibitor domain $\delta 3$ with 230 base pairs:

\section{primer I: ${ }^{3}$-TTCCCAGCCTTTTTGAATTTCA- ${ }^{5}$ primer II: ${ }^{3}$-TTAATCCGGAGGAAAACTATAAGAA- $-{ }^{\prime}$}

The pCRII ${ }^{\circledR}$-Kit (Invitrogen, De Shelp, The Netherlands) was used for cloning and sequencing the PCR fragment of each cell line. The PCR amplificates were confirmed by double stranded sequencing using the direct blotting technique (SERVA, Heidelberg, Germany)

\section{Cell culture}

Human umbilical vein endothelial cells (Promocell, Heidelberg, Germany) were incubated in serum-free growth medium containing human epidermal growth factor $(10 \mu \mathrm{g} / \mathrm{l})$, bovine brain extract $(12 \mathrm{mg} / \mathrm{l})$, hydrocortisone $(1 \mathrm{mg} / \mathrm{l})$ and antibiotics $(50 \mathrm{mg} / \mathrm{l})$. EA.hy 926 endothelial cell line was kindly provided by CoraJean S. Edgell (Department of Pathology, University of North Carolina, NC, USA) and cultivated in RPMI 1640, $100 \mathrm{~g} / 1$ foetal calf serum with $5 \mathrm{mmol} / \mathrm{l}$ hypoxanthine, $20 \mu \mathrm{mol} / 1$ aminopterin, $0.8 \mathrm{mmol} / 1$ thymidine. All other cell lines (chondrosarcoma SW1353, synovial sarcoma SW982, synovial cells (McCoy), leukaemic monocytes THP-1, endothelial cell line ECV304) were obtained from the American Type Culture Collection (Rockville, MA, USA) and cultivated in M199 medium with $100 \mathrm{~g} / \mathrm{l}$ foetal calf serum.

\section{Flow cytometry}

For flow cytometric analysis the cells were grown until $80 \%$ confluence, then removed in $0.5 \mathrm{~g} / 1$ trypsin and $0.2 \mathrm{~g} / 1$ ethylenediaminetetraacetic acid. The cells were washed twice in Dulbecco's phosphate-buffered saline containing $10 \mathrm{~g} / 1$ foetal calf serum and resuspended at $10^{6}$ cells per $100 \mu \mathrm{l}$. Each polyclonal IgG fraction was added in a final dilution of 1:100 from the stock solution. After $1 \mathrm{~h}$ incubation at room temperature and additional washing, the secondary polyclonal goat anti-rabbit fluorescein labelled antibody $\mathrm{F}\left(\mathrm{ab}^{\prime}\right)_{2}$-fragment (Dianova, Hamburg, Germany) was added in a final dilution of 1:200. After 1h incubation at room temperature the cells were washed twice in Dulbecco's phosphate-buffered saline containing $10 \mathrm{~g} / 1$ foetal calf serum and resuspended in $500 \mu \mathrm{l}$ Dulbecco's phosphate-buffered saline containing $10 \mathrm{~g} / \mathrm{l}$ foetal calf serum for flow cytometric analysis in a fluorescence activated cell sorting analyser using CELLQuest ${ }^{\circledR}$ software (Becton Dickinson, Heidelberg, Germany). Negative controls were performed with either no primary antibody or preimmune IgG fraction. For positive control a mouse anti-HLA-ABC monoclonal antibody (DAKO Diagnostica, Hamburg, Germany) was used.

\section{Immunohistochemistry}

The cells were washed three times in phosphate-buffered saline at $4{ }^{\circ} \mathrm{C}$ to remove traces of culture medium, then resuspended in phosphate-buffered saline at an approximate cell concentration of $2 \times 10^{9} /$. The suspension $(50-100 \mu \mathrm{l})$ was pipetted onto a premarked area of silanized glass slides and allowed to settle for 10

2) Abbreviations

cDNA, copy deoxyribonucleic acid

DNA, deoxyribonucleic acid

dNTP, 2'-deoxynucleoside 5'-triphosphate

PCR, polymerase chain reaction

RNA, ribonucleic acid 
min. Residual suspension was removed by tapping and the cells were air dried for a further $10 \mathrm{~min}$. The slides were then fixed in $30 \mathrm{~g} / 1$ paraformaldehyde in phosphate-buffered saline for $1 \mathrm{~h}$ and washed in distilled water. The slides were passed through graded aqueous solutions of absolute ethanol then air dried at $4{ }^{\circ} \mathrm{C}$. Prior to staining the preparations were rehydrated in phosphate buffered saline.

\section{Tissue factor pathway inhibitor activity assay}

The inhibitory activity of tissue factor pathway inhibitor in cell culture supernatant was measured by a modified chromogenic substrate assay based on the ability to inhibit factor $\mathrm{X}^{1)}$ activation by factor VIIa/tissue factor ${ }^{1)}$ complex. Tissue factor $(25 \mu \mathrm{l}$, dilution 1:80, Baxter, Unterschleißheim, Germany) and $25 \mu \mathrm{l}$ factor VII $(0.0125 \mathrm{U})$ were added to $25 \mu \mathrm{l} 0.075 \mathrm{~mol} / / \mathrm{CaCl}_{2}$ and $25 \mu \mathrm{l}$ factor $\mathrm{X}(0.025 \mathrm{U})$ and incubated for $15 \mathrm{~min}$ at $37^{\circ} \mathrm{C}$ with vigorously shaking. Heat-inactivated sample $(25 \mu \mathrm{l}$, dilution up to $1: 20$ ) was added, followed by incubation again for $15 \mathrm{~min}$ at $37^{\circ} \mathrm{C}$ with vigorous shaking. A further $25 \mu \mathrm{l}$ factor $\mathrm{X}(0.4 \mathrm{U})$ were then added immediately, and the incubation continued for $10 \mathrm{~min}$ at $37^{\circ} \mathrm{C}$. The chromogenic reaction was then started by adding $25 \mu \mathrm{l}$ synthetic substrate $(2.7 \mathrm{~mol} / \mathrm{l} \mathrm{N}$-benzoyl-Ile-GluGly-Arg-p-nitroanilide, Chromogenix, Essen, Germany). The absorbance was measured at $405 \mathrm{~nm}$ after $30 \mathrm{~min}$. The clotting factors and samples were diluted in assay buffer containing $0.05 \mathrm{~mol} / 1 \mathrm{Tris} / \mathrm{HCl}, 0.1 \mathrm{~mol} / 1 \mathrm{NaCl}$ and $10 \mathrm{~g} / 1$ human albumin (Armour Pharma, Eschwege, Germany), pH 8.0. For quantification the test sytem was calibrated with truncated recombinant tissue factor pathway inhibitor (19).

\section{Results}

\section{Determination of antisera specificity}

The antisera were used in a dot blot assay against each synthesized oligopeptide. Staining with a secondary anti-rabbit horse radish peroxidase monoclonal antibody was only observed with the corresponding antigen. Thus, we found no cross-reactivity with either of the other domain-specific recognition sites (tab. 1). Furthermore, free plasma tissue factor pathway inhibitor was detected in a dot blot assay by all antisera (data not shown). This indicates the specificity of the immunglobulin fractions toward the complete tissue factor pathway inhibitor protein and demonstrates the presence of all tissue factor pathway inhibitor domains in the plasma.

Tab. 1 Schematic presentation of the specificity of antisera against each oligopeptide. The peptides $\mathrm{P} \delta 1, \mathrm{P} \delta 2$ and $\mathrm{P} \delta 3$ were recognized only by the corresponding antisera against the reactive site of the Kunitz-type single domain. Phosphate-buffered saline was used as negative control.

\begin{tabular}{lllll}
\hline Peptides & \multicolumn{3}{l}{$\begin{array}{l}\text { Antisera against tissue factor } \\
\text { pathway inhibitor }\end{array}$} & $\begin{array}{l}\text { Phosphate- } \\
\text { buffered } \\
\text { saline }\end{array}$ \\
\cline { 2 - 5 } & $\delta 1$ & $\delta 2$ & $\delta 3$ & \\
\hline P 11 & + & - & - & - \\
P 20 & - & + & - & - \\
P 33 & - & - & + & - \\
\hline Plasma & + & + & + & - \\
Serum & + & + & + & - \\
\hline
\end{tabular}

Flow cytometric tissue factor pathway inhibitor detection with polyclonal IgG fractions

The purified IgG fractions of each antiserum were used to detect tissue factor pathway inhibitor on the cell surface. The titre was 1:100 with IgG stock solution prepared from $10 \mathrm{ml}$ rabbit serum. All tissue factor pathway inhibitor single domains were detected by the corresponding antiserum on the surface of endothelial cells (human umbilical vein endothelial cells) and endothelial cell lines (EA.hy 926, ECV304) by flow cytometry (fig. 1). Since tissue factor pathway inhibitor was not detected in the supernatant after trypsin/ethylenediaminetetraacetic acid treatment (data not shown) it is concluded that this treatment did not release the membranebound inhibitor. The fluorescence intensity in the fluorescein isothiocyanate channel (FL1) was approximately $50 \%\left(10^{2}\right.$ events) compared with the density of HLA-ABC antigens $\left(10^{3}\right.$ events). The overall tissue factor pathway inhibitor expression on endothelial cells and two endothelial cell lines was significantly higher than that on other cell lines such as synovial cells (McCoy), synovial sarcoma (SW982), chondrosarcoma cells (SW982) and leukaemic monocytes (THP-1) (fig. 2). This is in accordance with the observation that endothelial cells are the main source of the inhibitor.

\section{Immunostaining of fixed endothelial cells with the monospecific antisera}

In immunohistochemical experiments we were also able to stain fixed endothelial cells with each of the three
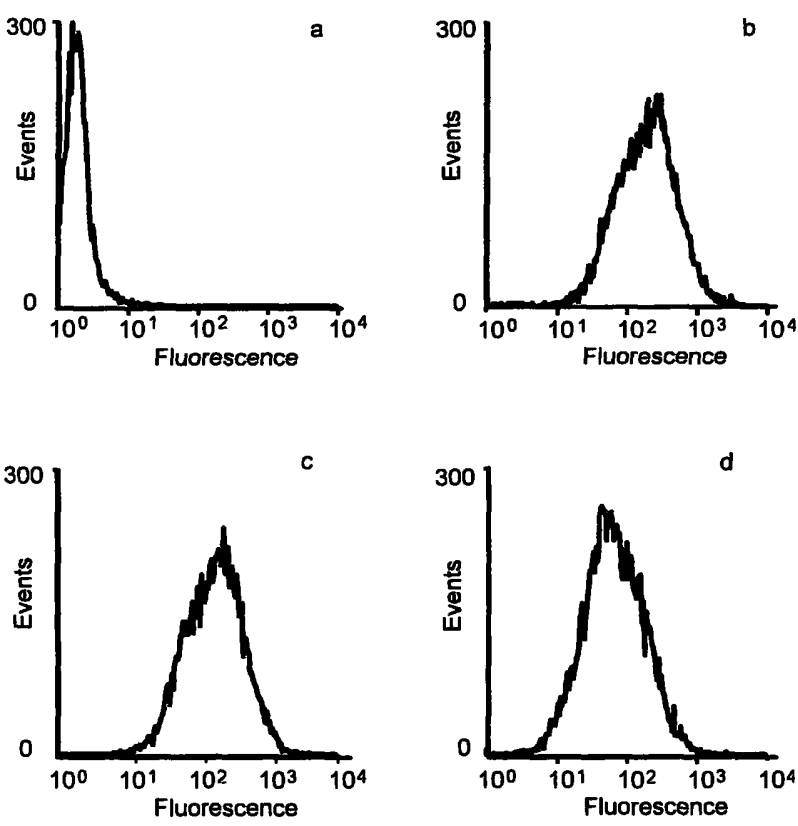

Fig. 1 Flow cytometric analysis of endothelial cells using tissue factor pathway inhibitor single domain specific IgG fractions. (a), negative control with IgG fraction from preimmunserum; (b), antidomain $\delta 1$ antibody; (c), anti-domain $\delta 2$ antibody; (d), anti-domain $\delta 3$ antibody. Fluorescence is given in arb. units. 

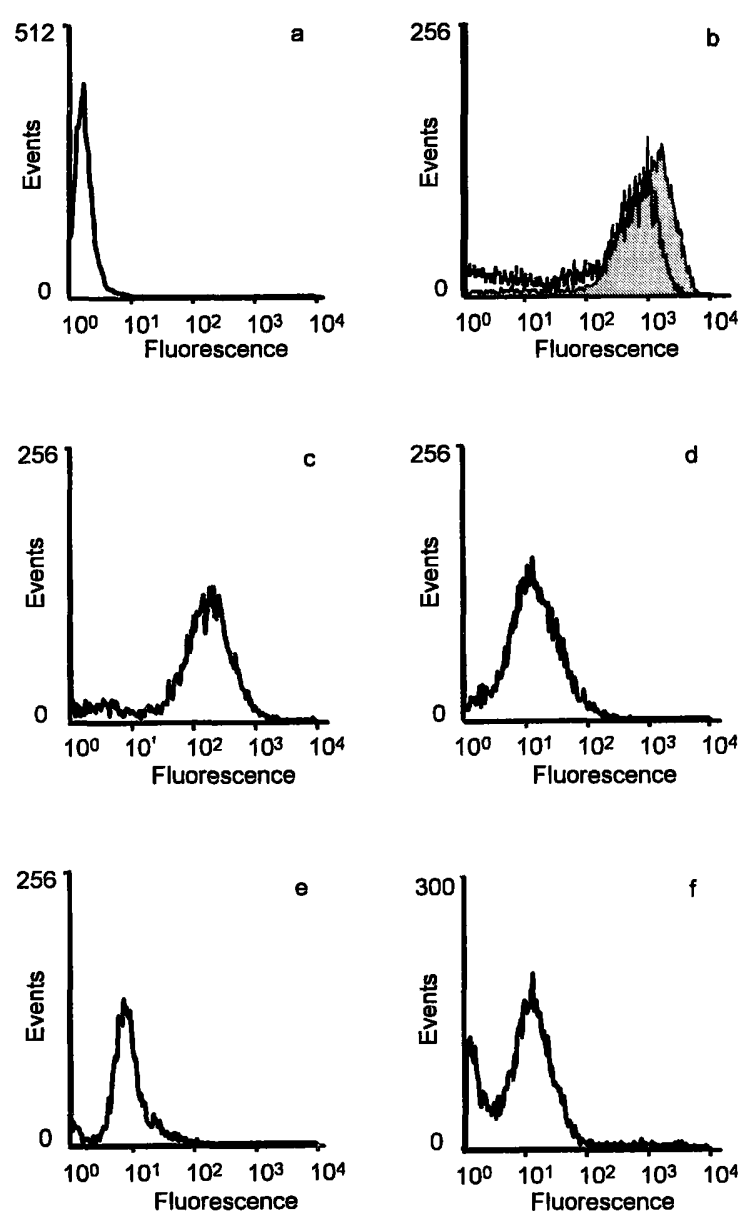

Fig. 2 Flow cytometric analysis of different cell lines using tissue factor pathway inhibitor specific IgG fraction against the single domain $\delta 1$.

(a) Preimmunserum as negative control, (b) endothelial cell line ECV304 [white] und EA.hy926 [gray], (c) chondrocytes, (d) monocytes, (e) chondrosarcoma, (f) synovial cells. Fluorescence is given in arb. units.

tissue factor pathway inhibitor-specific IgG fractions. The associated primary antibodies were detected with a secondary anti-rabbit horse radish peroxidase-coupled antibody. The optimal titres of IgG fractions were determined as 1:500.

Effect of heparin on the tissue factor pathway inhibitor presentation on the cell surface

To evaluate the tissue factor pathway inhibitor releasing effect of heparin, we analysed endothelial cells after heparin incubation by flow cytometry with our three polyclonal antibodies. To exclude fast tissue factor pathway inhibitor resynthesis and presentation, either the cellular protein synthesis or translocation were inhibited, using monensin or puromycin, respectively. In comparison with endothelial cells incubated without heparin, the tissue factor pathway inhibitor density on the surface of cells incubated after addition of low-molecular-weight heparin was only slightly decreased (fig. 3 ). Similar results were obtained in the presence and absence of monensin or puromycin.
Measurement of tissue factor pathway inhibitor concentration in the culture medium

The tissue factor pathway inhibitor concentration was measured in the cell culture medium $\left(10^{5}\right.$ cells per well) of endothelial cells after addition of $10000 \mathrm{U} / 1$ heparin and without heparin over a period of 48 hours by a chromogenic substrate assay. Our results clearly demonstrate a heparin-mediated tissue factor pathway inhibitor release from endothelial cells into the extracellular space (fig. 4). Incubation with heparin (10000 U/l) results in a 2-4 fold increased tissue factor pathway inhibitor concentration $(140-280 \mu \mathrm{g} / 1)$ compared with cells cultivated without heparin $(80-130 \mu \mathrm{g} / \mathrm{l})$.

\section{Detection of tissue factor pathway inhibitor-specific mRNA}

In addition to endothelial cells and endothelial cell lines ECV304/EA.hy 926, tissue factor pathway inhibitorspecific DNA transcription products were also detected in chondrosarcoma (SW1353), synovial sarcoma (SW982), synovial cells (McCoy) and leukaemic monocytes (THP-1) by reverse transcription PCR. The cloned PCR-fragments were identified as the coding region of
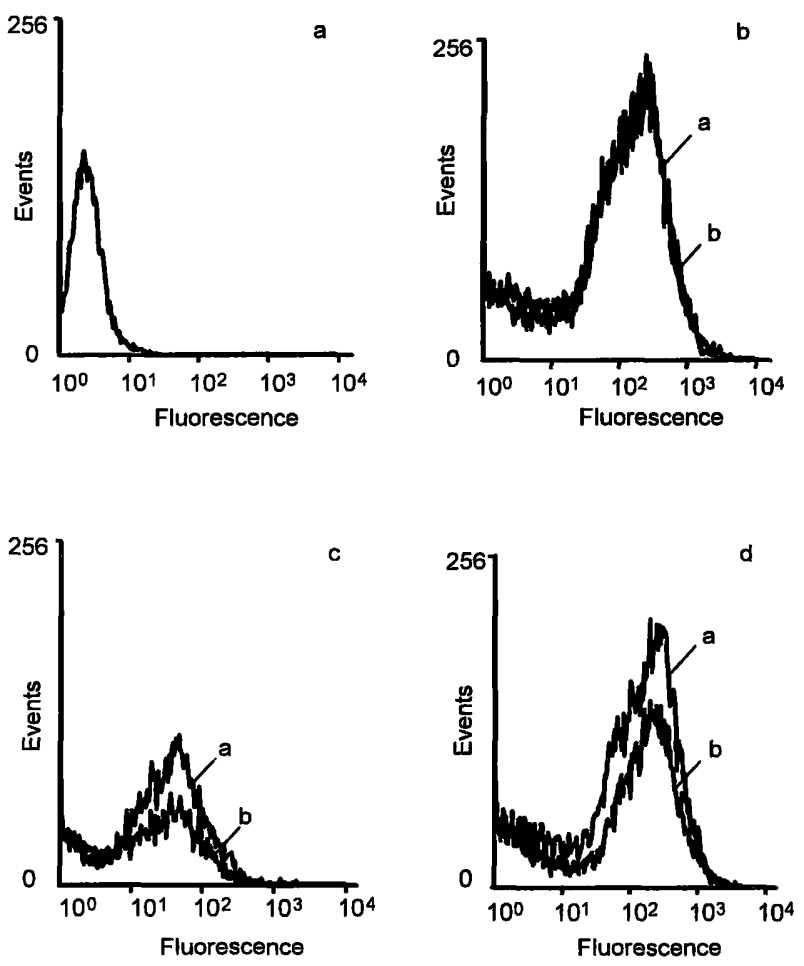

Fig. 3 Flow cytometric analysis of endothelial cells under the influence of heparin. (a) Negative control with IgG fraction from preimmunserum; (b) anti-Kunitz-type domain $\delta 1$ antibody, (a) without heparin, (b) after addition of $10000 \mathrm{U} / 1$ low-molecular-weight heparin; (c) anti-domain $\delta 2$ antibody, (a) without heparin, (b) after incubation with $10000 \mathrm{U} / 1$ low-molecular-weight heparin for 30 minutes; (d) anti-domain $\delta 3$ antibody, (a) without heparin, (b) after incubation of $10000 \mathrm{U} / 1$ low-molecular-weight heparin for 30 minutes. Protein resynthesis was inhibited by puromycin. Incubation with monensin gave similar results (data not shown). Fluorescence is given in arb. units. 


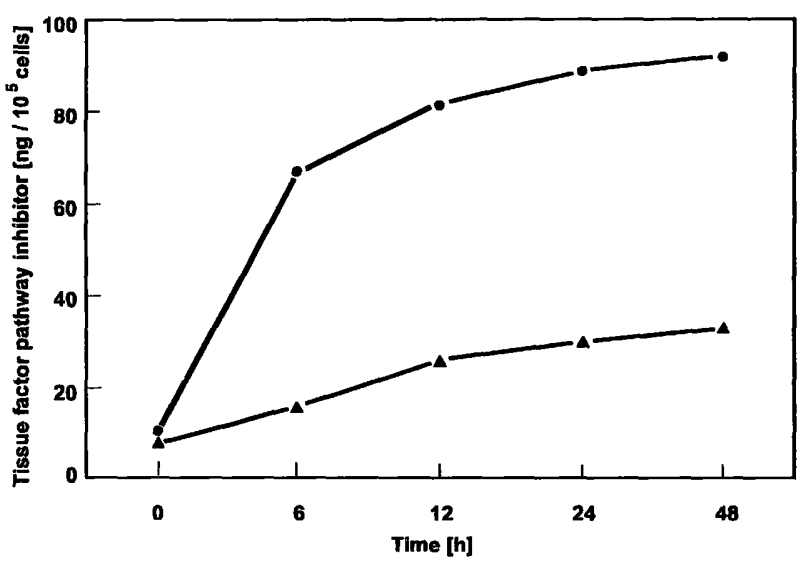

Fig. 4 Measurement of the tissue factor pathway inhibitor concentration in endothelial cell culture supernatant using a chromogenic substrate assay. The cells were incubated with $(\bullet-\bullet)$ or without $(\Delta-\Delta)$ heparin $(10000 \mathrm{U} / \mathrm{l})$ over a period of two days. The values represent the mean (per $10^{5}$ cells).

tissue factor pathway inhibitor domain $\delta 3$ by DNA sequencing (data not shown).

\section{Discussion}

Tissue factor pathway inhibitor, which is mainly synthesized by endothelial cells, is a natural anticoagulant in the extrinsic pathway of blood coagulation (20). The main activity of tissue factor pathway inhibitor is to downregulate the initial activation of coagulation resulting from exposure of tissue factor to the blood $(21-22)$. This activity is increased after in vivo administration of low-molecular-mass heparin (23).

Heparin and fractionated low-molecular-mass heparin (24) induce increased plasma levels of tissue factor pathway inhibitor in vivo after subcutaneous administration and in endothelial cell culture supernatant (12-14). The increased inhibitor concentration appears to be mediated by the release of tissue factor pathway inhibitor from the endothelial cell surface where tissue factor pathway inhibitor is possibly present in association with proteoglycans (25), or from intracellular stores. Thus, tissue factor pathway inhibitor may function as an important regulator of thrombin formation on the vascular surface.

Our interest was focused on tissue factor pathway inhibitor presentation on the cell surface. Determination of the surface expression by flow cytometric methods was made possible by our new monospecific polyclonal antibodies (fig. 5). These antibodies were obtained by immunization of rabbits with synthetic oligopeptides representing the reactive site of each Kunitz-type domain.

Each tissue factor pathway inhibitor single domain was detected by the corresponding antiserum on the surface of endothelial cells (human umbilical vein en- dothelial cells, ECV304, EA.hy 926), synovial cells, synovial sarcoma, chondrosarcoma and leukaemic monocytes. We also determined tissue factor pathway inhibitor-specific mRNA-transcripts in these cell lines to ensure that tissue factor pathway inhibitor gene transcription had occurred.

As the main source of vascular tissue factor pathway inhibitor, endothelial cells showed a higher surface expression of the inhibitor compared with other tested cell lines. According to the results of flow cytometry, heparin did not release surface bound tissue factor pathway inhibitor from endothelial cells. Even when protein synthesis and translocation were inhibited by monensin or puromycin, heparin did not alter significantly the tissue factor pathway inhibitor density on the endothelial cell surface. However, we found an increased tissue factor pathway inhibitor concentration in the extracellular space with our chromogenic substrate assay. This suggests that membrane-bound tissue factor pathway inhibitor is not the source of elevated inhibitor concentrations after heparin induction. Increased tissue factor pathway inhibitor levels, as measured in the cell culture supernatant after heparin incubation, might be derived from intracellular stores, as shown for von Willebrand factor, which is derived from Weibel-Palade bodies or secreted directly from the endothelial cytosol (26).

The third domain $\delta 3$ of tissue factor pathway inhibitor has been postulated as the binding site on the cell surface, where it mediates, in combination with the $\mathrm{C}$-terminus, the association with other molecules, e. g. proteoglycans, lipoproteins and heparin $(5,27)$. The antibody to domain $\delta 3$ (Pro ${ }^{192}-\operatorname{Arg}^{204}$ ) bound to the cell surface with no decrease of affinity. Thus, the association of the inhibitor with cell membrane proteoglycans did not involve this region of the tissue factor pathway inhibitor protein. Furthermore, the recognition of domain $\delta 3$ was

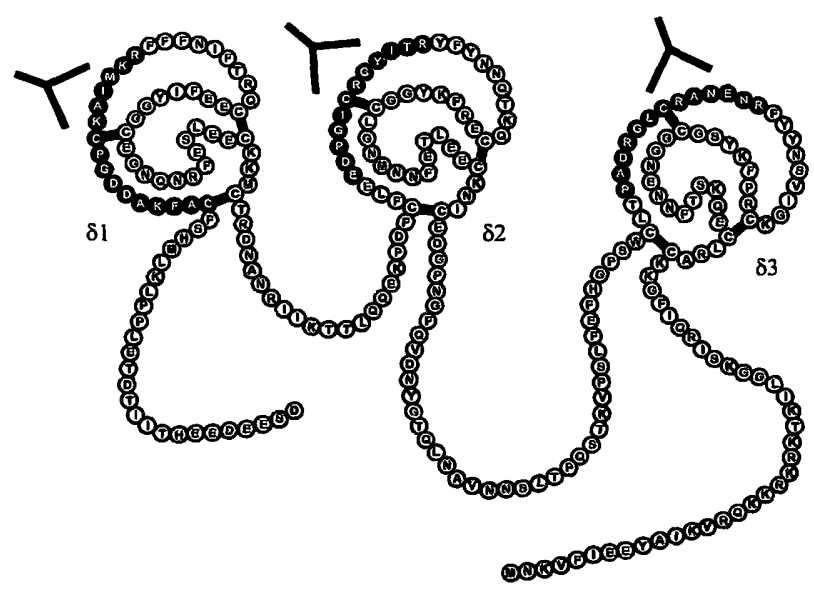

Fig. 5 Secondary structure of tissue factor pathway inhibitor. The black amino acids demarcate both the reactive site of the Kunitztype domain and the corresponding synthetic oligopeptide sequence for immunization. 
not influenced by heparin. We therefore suggest that the C-terminus, and not the third domain, is probably the tissue factor pathway inhibitor binding site. The releasing effect of heparin remains unclear even though strong evidence points to an intracellular mechanism.

\section{References}

1. Novotny WF, Girard TF, Miletich JP, Broze GJ Jr. Platelets secrete a coagulation inhibitor functionally and antigenically similar to the lipoprotein-associated coagulation inhibitor. Blood 1988;76:2020-5.

2. Hamamoto T, Yamamoto $M$, Nordfang $O$, Listke Petersen JG, Foster DC, Kisliel W. Inhibitory properties of full length and truncated recombinant tissue factor pathway inhibitor (TFPI). J Biol Chem 1993; 268:8704-10.

3. Marlar RA, Kleiss AJ, Griffin JH. An alternative extrinsic pathway of human blood coagulation. Blood 1982; $60: 1352-8$.

4. Wun TC, Kretzmer KK, Girard TJ, Miletich JP, Broze GJ. Cloning and characterization of a cDNA coding for the lipoprotein-associated coagulation inhibitor shows that it consists of three tandem Kunitz-type inhibitory domains. J Biol Chem 1988; 263:6001-4.

5. Girard TJ, Eddy R, Wesselschmidt RL. Structure of the human lipoprotein-associated coagulation inhibitor gene. Intron/exon gene organization and localization of the gene to chromosome 2. J Biol Chem 1991; 266:5036-41.

6. Hansen JB, Huseby NE, Sandset PM, Svensson B, Lyngmo V, Nordoy A. Tissue factor pathway inhibitor and lipopolysaccharides - evidence for association with and regulation by LDL in human plasma. Arterioscler Thromb 1994; 14:223-9.

7. Bajaj MS, Kuppuswamy MN, Saito H, Spitzer SG, Bajaj SP. Cultured normal human hepatocytes do not synthesize lipoprotein-associated coagulation inhibitor: evidence that endothelium is the principle site of its synthesis. Proc Natl Acad Sci USA 1990; 87:8869-73.

8. Brinkmann T, Kähnert H, Prohaska W, Nordfang O, Kleesiek $\mathrm{K}$. Synthesis of tissue factor pathway inhibitor in human synovial cells and chondrocytes makes joints the predilected site of bleeding in haemophiliacs. Eur J Clin Chem Clin Biochem 1994; 32:313-7.

9. Hansen JB, Huseby KR, Huseby NE, Sandset PM, Hanssen TA, Nordoy A. Effect of cholesterol lowering on intravascular pools of TFPI and its anticoagulant potential in type II hyperlipoproteinemia. Arterioscler Thromb 1995; 15:879-85.

10. Warshawsky I, Broze GJ, Schwarz AL. The low density lipoprotein receptor-related protein mediates the cellular degradation of tissue factor pathway inhibitor. Proc Natl Acad Sci USA 1994; 91:6664-8.

11. Sandset PM, Albigaard U, Larsen ML. Heparin induces release of extrinsic pathway inhibitor (EPI). Thromb Res 1988; $50: 803-13$

12. Harenberg J, Malsch R. Heene DL. Tissue factor pathway inhibitor: proposed heparin recognition region. Blood Coagul Fibrinol 1995; 6:50-6.

13. Lindahl AK, Abildgaard U, Stokke G. Extrinsic pathway inhibitor after heparin injection: increased response in cancer patients. Thromb Res 1990; 59:651-6.

14. Cadroy Y, Gaspin D, Lormeau JC, Boneu B, Sié P. Heparin reverses the procoagulant properties of stimulated endothelial cells. Thromb Haemostasis 1996; 75:190-5.

15. Enjyoji K, Miyata T, Kamikubo Y, Kato H. Effect of heparin on the inhibition of factor $\mathrm{Xa}$ by tissue factor pathway inhibi-

\section{Acknowledgements}

We are grateful to Ms. Grainne Delany for linguistic advice. This work was supported by the Deutsche Forschungsgemeinschaft, Bonn-Bad Godesberg, Sonderforschungsbereich 223, within the project B08.

tor: a segment, $\mathrm{Gly}^{212}-\mathrm{Phe}^{243}$, of the third Kunitz domain is a heparin binding site. Biochemistry 1995; 34:5725-35.

16. Broze GJ. Tissue factor pathway inhibitor. Thromb Haemostasis $1995 ; 74: 90-3$.

17. Tiemann C, Brinkmann T, Prohaska W, Kleesiek K. Effect of cyclosporine $A$ on the release of tissue factor pathway inhibitor (TFPI) in plasma of heart transplant patients and endothelial cell culture medium. Ann Haematol 1995; 70:A77.

18. Tiemann C, Brinkmann T, Prohaska W, Kleesiek K. Elevated concentrations of tissue factor pathway inhibitor (TFPI) in immunosuppressed heart transplant patients. Eur J Clin Chem Clin Biochem 1995; 33:A87.

19. Tiemann C, Prohaska W, Körfer, R, Körner, M, Brinkmann T, Kleesiek K. Effect of cyclosporine A on the release of tissue factor pathway inhibitor (TFPI) from endothelial cells in heart transplant patients and cell culture. Eur J Clin Chem Clin Biochem 1997; 35:661-7.

20. Broze GJ. Tissue factor pathway inhibitor and the current concept of blood coagulation. Blood Coagul Fibrin 1995; 6:7-13.

21. Rao LV, Rapaport I. Studies of a mechanism inhibiting the initiation of the extrinsic pathway of coagulation. Blood 1987; 69:645-51

22. Van't Veer C, Hackeng TM, Delahaye C, Sixma JJ, Bouma $\mathrm{BN}$. Activated factor $\mathrm{X}$ and thrombin formation triggered by tissue factor on endothelial cell matrix in a flow model: effect of the tissue factor pathway inhibitor. Blood 1994; $84: 1132-42$.

23. Hirsch J, Levine MN. Low molecular weight heparin. Blood 1992; 79:1-17.

24. Hoppenstedt DA, Jeske W, Farred J, Bermes EW. The role of tissue factor pathway inhibitor in the mediation of the antithrombotic actions of heparin and low-molecular weight heparin. Blood Coagul Fibrin 1995; 6:57-64.

25. Broze GJ. Tissue factor pathway inhibitor and the revised theory of blood coagulation. Ann Rev Med 1995; 46:103-12.

26. Collins P, Wilkie M, Razak K, Abbot S, Harley S, Bax C, et al. Cyclosporine and cremaphor modulate von Willebrand factor release from cultured human endothelial cells. Transplantation 1993; 56:1218-23.

27. Valentin S, Nordfang O, Bregengard C, Wildgoose P. Evidence that the C-terminus of the TFPI is essential for its in vitro and in vivo interaction with lipoproteins. Blood Coagul Fibrin 1993; 4:713-20.

\section{Received July 10/ September 4, 1997}

Corresponding author: Dr. Thomas Brinkmann, Institut für Laboratoriums- und Transfusionsmedizin, Herz- und Diabeteszentrum Nordrhein-Westfalen, Universitätsklinik der Ruhr-Universität Bochum, Georgstraße 11, D-32545 Bad Oeynhausen, Germany Tel: +49-5731-971390; Fax: +49-5731-972307, e-mail: HDZ. ILTM@post.uni-bielefeld.de 